\title{
Critical appraisal of bilastine for the treatment of allergic rhinoconjunctivitis and urticaria
}

This article was published in the following Dove Press journal:

Therapeutics and Clinical Risk Management

2 May 2013

Number of times this article has been viewed

\author{
Belen Sadaba \\ Jose Ramon Azanza \\ Almundena Gomez-Guiu \\ Raquel Rodil \\ Clinical Pharmacology Service, \\ Clinica Universidad de Navarra, \\ Navarra, Spain
}

Correspondence: Belen Sadaba

Clinical Pharmacology Service,

Clinica Universidad de Navarra,

C/PIO XII 36, 3I 008 Pamplona,

Navarra, Spain

Tel +34948296 695

Fax +34948296500

Email bsadaba@unav.es

\begin{abstract}
Bilastine is a second generation antihistamine indicated for the treatment of seasonal or perennial allergic rhinoconjunctivitis and chronic urticaria with a daily dose of $20 \mathrm{mg}$, in adults and children over 12 years of age. The efficacy of bilastine has been shown to be similar to that of the comparator drugs for the control of the nasal and nonnasal symptoms of allergic rhinoconjunctivitis, while also showing a subjective improvement in the quality of life and in overall clinical impression. For chronic urticaria the symptoms (itching and the development of papules) lessens from the second day of treatment onwards, in a similar way to other antihistamines used as comparators. Bilastine should not be administered at meal times to avoid interference with the absorption process. It is not distributed to the central nervous system, is scarcely metabolized, and elimination is through the kidneys and feces, with a 14-hour elimination half-life. It has no effect on cytochrome P450. During clinical development, bilastine was shown to be a drug that is adequately tolerated, with a similar effect to placebo with regard to drowsiness and changes in heart rate. In relation to its use, headaches were the most frequent adverse effect to be reported. No cardiotoxic effects have been observed, and the therapeutic dose does not alter the state of alertness.
\end{abstract}

Keywords: bilastine, allergic rhinoconjunctivitis, chronic urticaria, second generation antihistamine, drowsiness, CYP450

\section{Bilastine}

Bilastine is a recently marketed, orally administered antihistamine for the treatment of allergic rhinoconjunctivitis and chronic urticaria in adults and adolescents. The treatment of both disorders with antihistamines has been clearly established. ${ }^{1}$ Second generation antihistamines have surpassed first generation ones due to their improved tolerance, primarily based on their lack of anticholinergic effects and lower risk of cardiotoxicity. However, second generation antihistamines are able to cross the blood-brain barrier and, therefore, can induce drowsiness. Likewise, many of these antihistamines are metabolized by cytochrome $\mathrm{P} 450$ enzymes, and thus can possibly interact with other drugs. As discussed below, these characteristics have been addressed and modified with bilastine. The aim of this paper is to assess the present situation of the aforementioned antihistamine for the treatment of chronic urticaria and allergic rhinoconjunctivitis, through an evaluation of the results published regarding the efficacy and safety of this new drug.

\section{Pharmacodynamics}

Bilastine, or 2-[4-[2-[4-[1-(2-ethoxyethyl) benzimidazol-2-yl] piperidin-1-yl] ethyl] phenyl]-2-methylpropionic acid (Figure 1), is a molecule with a molecular weight of 463.6 Daltons. Based on bilastine's structure, it is classified within the group 


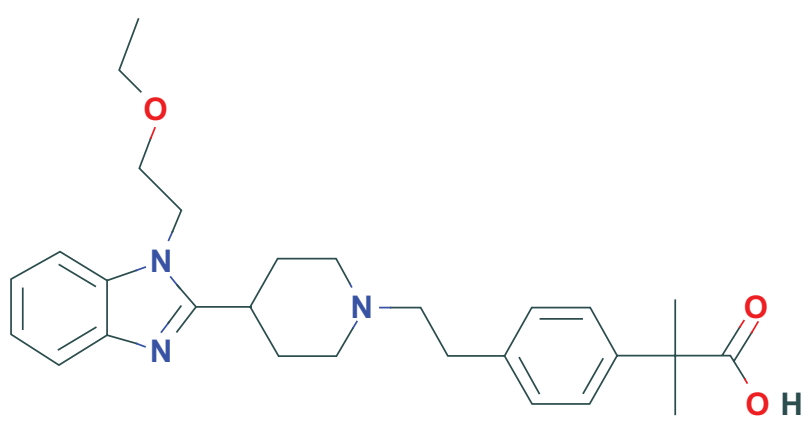

Figure I Chemical structure of bilastine.

of new antihistamines, as a second generation original molecule.

Bilastine is highly selective for histamine receptor $(\mathrm{H} 1)$ binding, without inhibiting other receptors (muscarinic, adrenergic, serotonergic, other histamine receptors, bradykinin, leukotriene d4, or calcium). It shows great affinity for the H1, comparable to other antihistamines, such as astemizole or diphenhydramine, and a three and five fold greater affinity than fexofenadine and cetirizine, respectively. ${ }^{2}$ The inhibition of this receptor blocking is dose dependent. The antimuscarinic effect was specifically studied in preclinical trials and in healthy volunteers alike; this effect was not observed in the cellular models. In humans, no change was observed in pupillary reactivity following treatment with different dose levels of bilastine (20,40, and $80 \mathrm{mg}$ /day) over a 7-day period. ${ }^{3}$ It can therefore be concluded that bilastine does not present undesirable anticholinergic effects associated with first generation antihistamines.

In different murine models, bilastine antagonizes the effect of histamine in a concentration-dependent manner (inhibiting increased capillary permeability, decreased microvascular extravasation, and decreased bronchospasm), with a similar potency to fexofenadine and greater than that of cetirizine. The antihistaminic effect of bilastine had a longer lasting duration than observed for cetirizine. ${ }^{4}$

Inhibition of the release of histamine, interleukin (IL)-4, and tumor necrosis factor- $\alpha$ was observed in peripheral blood mast cells and granulocytes following bilastine treatment. ${ }^{5}$

In a phase I study on healthy volunteers in which dose levels of 2.5 and $50 \mathrm{mg}$ were evaluated, a reduction in histamine induced flare and wheal was observed, similar to that observed with cetirizine, although the higher dose levels for bilastine, (20 and $50 \mathrm{mg}$ ) meant faster results. ${ }^{6}$

\section{Pharmacokinetics}

Bilastine is marketed as tablets and its pharmacokinetic properties were evaluated in preclinical and clinical trials, several of which were phase I trials (see Table 1). The pharmacokinetic parameters of bilastine are shown in Table 1.

Following oral administration, bilastine is rapidly absorbed, reaching a maximum concentration $\left(\mathrm{C}_{\max }\right)$ in 1 to 1.5 hours. Absorption is a first order process, observing dose linearity in the range from 2.5 to $220 \mathrm{mg}$, for single and multi doses alike, with no sign of accumulation after 14 days of treatment. ${ }^{7,8}$ This is a rapid process, with an absorption constant of $1.5 \mathrm{~h}^{-1}$. The oral administration of $20 \mathrm{mg}$, considered to be the therapeutic dose, achieved a mean maximum concentration of $220 \mathrm{ng} / \mathrm{ml} 1.3$ hours after administration, with subsequent biexponential elimination.

Bilastine has a bioavailability of $60 \%$. It is a substrate of the membrane transporters present in the intestinal lumen cells, the $\mathrm{P}$ glycoprotein, and the organic anion-transporting polypeptide. The $\mathrm{P}$ glycoprotein is responsible for incomplete bioavailability, being an efflux protein, while the organic anion-transporting polypeptide facilitates absorption. Both transporters are present in the luminal membrane of the duodenum, indicating a powerful interaction between them, working in opposite directions. Both are liable to interactions when administered with fruit juices and some drugs. ${ }^{9}$

Bioavailability is lessened when administered together with food rich in fats and with substances that modify the membrane transporter activity. In a study involving healthy volunteers, a $30 \%$ reduction in bioavailability was observed when administered together with a high fat meal and a $25 \%$ reduction when the meal had standard fat content. ${ }^{10,11}$ Grapefruit juice in particular caused a $30 \%$ reduction in bioavailability. ${ }^{10,11}$

Bilastine has a two compartment distribution, with an apparent volume of distribution of $1.29 \mathrm{l} / \mathrm{kg}$. It binds to plasma proteins in a proportion from $84 \%$ to $90 \%$.

Table I Pharmacokinetic parameters of bilastine from single dose studies ${ }^{11,18,23,27}$

\begin{tabular}{ll}
\hline & Healthy volunteers \\
\hline Dose $(\mathrm{mg}) /$ route & $20 /$ oral \\
$\mathrm{C}_{\max }(\mathrm{ng} / \mathrm{mL})$ & $182.4-256.56$ \\
$\mathrm{~T}_{\max }($ hour $)$ & $1.1 \mathrm{I}-1.56$ \\
$\mathrm{AUC}_{0-\mathrm{t}}(\mathrm{ng} / \mathrm{mL} * \mathrm{~h})$ & $876-1289.2$ \\
$\mathrm{~F}$ oral $(\%)$ & $6 \mathrm{I}$ \\
$\mathrm{TI} / 2$ alpha (hour) & 2.1 \\
$\mathrm{TI} / 2$ beta (hour) & 14.5 \\
$\mathrm{Vc}(\mathrm{L})$ & 59.2 \\
$\mathrm{VP}(\mathrm{L})$ & 30.2 \\
$\mathrm{Cl}(\mathrm{L} /$ hour $)$ & 18.1 \\
\hline $\mathrm{Ab}$
\end{tabular}

Abbreviations: $\mathrm{AUC}_{0-\mathrm{t}}$, area under the plasma drug concentration-time curve between 0 and $t ; C_{\max }$, maximum plasma concentration; $C L$, clearance; $t$, time; $T_{\text {max }}$, time to reach $\mathrm{C}_{\max } ; \mathrm{F}$, bioavailability; $\mathrm{tl} / 2$ alpha, half-life of distribution; $\mathrm{tl} / 2$ beta, halflife of elimination; $\mathrm{V}_{c}$, volume of distribution in central compartment; $\mathrm{V}_{\mathrm{p}}$, volume of distribution in peripheral compartment. 
In studies on animals with radiolabeled bilastine, the drug was distributed in the gastrointestinal tract and liver, without reaching the brain. ${ }^{12}$

Bilastine is scarcely metabolized, and is excreted unchanged through the kidneys and feces. A mass balance study showed that $33 \%$ of bilastine was excreted in the urine and $67 \%$ in the feces. ${ }^{13}$ A study with hepatocyte cultures and liver microsomes demonstrated the non-existence of cytochrome P450 mediated metabolization, nor was any inhibiting or inducing effect observed with regard to this same enzyme. ${ }^{7}$ This lack of inhibition is one of the characteristics that makes bilastine a compound of interest, according to the recommendations published by a group of experts on the treatment of allergic rhinitis; ${ }^{1} 96 \%$ of the dose administered was eliminated in 24 hours and at 72 hours it was completely eliminated from urine, with an elimination half-life of around 14 hours. Renal function impairment did not significantly alter the pharmacokinetics of bilastine ${ }^{10}$ although an increase in the plasma concentrations of the antihistamine was observed. In general, this suggests that there is no need to modify the dose in the event of renal impairment, although this precaution should be taken into account in situations in which the concentrations of bilastine may be increased in the blood as a result of the concomitant administration of $\mathrm{P}$ glycoprotein inhibitors, as was observed with ketoconazole. ${ }^{14}$

No evaluation of bilastine administration to patients with liver damage has been made, although given the fact that bilastine does not metabolize, no pharmacokinetic modification or the need for dosage adjustment whatsoever is to be expected for these patients.

No differences in bilastine pharmacokinetics have been observed with regard to sex or age, except for the highest maximum plasma concentration $\left(\mathrm{C}_{\max }\right)$ values in young women (18-35 years). In a population pharmacokinetics analysis, no influence of various covariables was observed (age, weight, height, sex, heart rate, serum albumin, creatinine, bilirubin, liver transaminases, alkaline phosphates, or urea). ${ }^{?}$

Based on data from adults, it was estimated that the dose for children aged 2 to 12 years should be $10 \mathrm{mg}$ per day and $5 \mathrm{mg}$ per day for children under the age of two, ${ }^{15}$ although studies are currently being conducted to confirm this dose.

The possibility of bilastine interacting with food and other drugs was previously evaluated. As mentioned, grapefruit juice reduces the bioavailability of bilastine. ${ }^{10,11}$ The mechanism responsible for this interaction could be the inhibition of the organic anion-transporting polypeptide membrane transporter, which facilitates the absorption of some drugs. ${ }^{9}$ This effect on the transporter could be avoided by taking bilastine either one hour before or two hours after the intake of juices or food. Some substrate drugs or inhibitors of this transporter, such as ritonavir or rifampicin, could reduce bilastine plasma concentrations, ${ }^{16}$ although this point has not been specifically evaluated.

No effect of bilastine has been observed on the pharmacokinetics of ketoconazole in healthy volunteers. ${ }^{14}$ On the other hand, exposure to bilastine increased as a result of coadministration with ketoconazole, which doubled the exposure of the antihistamine, probably due to the inhibitor effect on the membrane transporters, such as $\mathrm{P}$ glycoprotein, in the intestinal lumen without modifying the hepatic clearance. ${ }^{17}$

No interaction was observed with the central nervous system depressors, such as lorazepam ${ }^{18}$ or alcohol. ${ }^{19}$

\section{Pharmacokinetics/pharmacodynamics}

When jointly evaluating the pharmacokinetic and pharmacodynamic data, it was concluded that bilastine is characterized by two compartment kinetics, with a rapid absorption phase and a maximum response 4 hours after administration. The pharmacodynamics of the disappearance of the wheal or flare was fitted to an indirect response model to define a concentration that produces a $50 \%$ inhibition $\left(\mathrm{IC}_{50}\right)$ of $5.15 \mathrm{ng} / \mathrm{ml}$ and $1.25 \mathrm{ng} / \mathrm{ml}$, respectively. With a daily administration of $20 \mathrm{mg}$ of bilastine to adults, the plasma concentrations remain above these values for 20 and 24 hours, respectively, indicating that a once a day administration is adequate. ${ }^{7}$ In a simulation performed for children aged from 2 to 12 , the $10 \mathrm{mg}$ dose was sufficient to maintain the plasma concentrations above this value for the entire administration interval. ${ }^{15}$

\section{Efficacy}

Efficacy evaluation of bilastine from clinical investigation is shown in Table 2.

The onset of action and the duration of the antihistaminic effect are both decisive factors in selecting an antihistamine. Along these lines, an evaluation was made of the effects of bilastine on allergen-induced nasal and eye symptoms in 75 patients allergic to pollen. The patients were exposed to controlled concentrations of pollen using a standard allergy provocation method (Vienna Challenge Chamber). ${ }^{20}$ The subjects underwent two provocation tests with pollen on two consecutive days, for 6 hours on the first day and for 4 hours on the second day. The nasal symptoms were assessed every 
Table 2 Bilastine efficacy determined during clinical investigation

\begin{tabular}{|c|c|c|c|}
\hline Author & Study design & Primary endpoint & Efficacy \\
\hline $\begin{array}{l}\text { Bachert } \\
\text { et a }\left.\right|^{29}\end{array}$ & $\begin{array}{l}\text { Seasonal allergic rhinitis }(\mathrm{n}=72 \mathrm{I}) \text {. } \\
\text { Randomized, double blind, placebo- } \\
\text { controlled, parallel group, } 14 \text { days, } \\
\text { bilastine } 20 \mathrm{mg} \text {, desloratadine } 5 \mathrm{mg} \text {, } \\
\text { and placebo }\end{array}$ & $\begin{array}{l}\text { Mean AUC of the reflective TSS from } \\
\text { day } 0 \text { to day } 14 \text {, composed of NSS } \\
\text { (congestion, rhinorrhea, sneezing, and } \\
\text { itch) and NNSS (ocular itching, burning, } \\
\text { redness, sensation of foreign body in eye, } \\
\text { tearing, and itching of ears and/or palate) }\end{array}$ & $\begin{array}{l}\text { NSD between active treatments } \\
\text { but significantly more effective } \\
\text { than placebo in reducing AUC- } \\
\text { TSS over the entire treatment } \\
\text { period, improving the NSS, NNSS, } \\
\text { rhinitis-associated discomfort, } \\
\text { rhinoconjunctivitis, and quality of life }\end{array}$ \\
\hline $\begin{array}{l}\text { Kuna } \\
\text { et } \mathrm{al}^{30}\end{array}$ & $\begin{array}{l}\text { Seasonal allergic rhinitis }(\mathrm{n}=68 \mathrm{I}) \text {. } \\
\text { Randomized, double blind, placebo- } \\
\text { controlled, parallel group, } 14 \text { days, } \\
\text { bilastine } 20 \mathrm{mg} \text {, cetirizine } 10 \mathrm{mg} \text {, } \\
\text { and placebo }\end{array}$ & $\begin{array}{l}\text { Mean AUC of the reflective TSS from day } \\
0 \text { to day } 14 \text {, calculated daily as the sum of } \\
\text { four nasal (rhinorrhea, congestion, itching } \\
\text { and sneezing) and three nonnasal, ocular } \\
\text { symptoms (tearing, redness and itching) }\end{array}$ & $\begin{array}{l}\text { NSD between active treatments } \\
\text { but significantly more effective than } \\
\text { placebo in reducing AUC-TSS over } \\
\text { the entire treatment period }\end{array}$ \\
\hline $\begin{array}{l}\text { Zuberbier } \\
\text { et } \mathrm{al}^{37}\end{array}$ & $\begin{array}{l}\text { Chronic idiopathic urticaria }(\mathrm{n}=525) \text {. } \\
\text { Double-blind, randomized, placebo- } \\
\text { controlled, } 28 \text { days, bilastine } 20 \mathrm{mg} \text {, } \\
\text { levocetirizine } 5 \mathrm{mg} \text {, and placebo }\end{array}$ & $\begin{array}{l}\text { TSS was calculated as the sum of scores } \\
\text { for pruritus, number of wheals, and the } \\
\text { maximum wheal size recorded in the } \\
\text { patients' diaries each day, from day } \\
0 \text { to day } 28\end{array}$ & $\begin{array}{l}\text { NSD between active treatments } \\
\text { more effective than placebo to } \\
\text { improve Dermatology Life Quality } \\
\text { Index, general discomfort, and } \\
\text { sleep disruption. Treatment with } \\
\text { bilastine and levocetirizine reduced } \\
\text { instantaneous and reflective TSS } \\
\text { in a similar manner }\end{array}$ \\
\hline $\begin{array}{l}\text { Sastre } \\
\text { et } \mathrm{al}^{31}\end{array}$ & $\begin{array}{l}\text { Perennial allergic rhinitis }(\mathrm{n}=650) \text {. } \\
\text { Randomized, placebo-controlled, } \\
\text { double-blind, parallel-group, } 4 \text { weeks, } \\
\text { bilastine } 20 \mathrm{mg} \text {, cetirizine } 10 \mathrm{mg} \text {, } \\
\text { and placebo }\end{array}$ & $\begin{array}{l}\text { Mean AUC of the reflective TSS from } \\
\text { day } 0 \text { to day 28: total of } 6 \text { reflective or } \\
\text { instantaneous symptom scores (T6SS) as } \\
\text { well as T4NSS (rhinorrhea, nasal itching, } \\
\text { sneezing, nasal congestion) and T2OSS } \\
\text { (ocular redness, tearing) }\end{array}$ & $\begin{array}{l}\text { Statistically significant differences } \\
\text { existed between active treatments } \\
\text { and placebo in the mean AUC of } \\
\text { T6SS and T4NSS (not in South } \\
\text { Africa patients). Bilastine } 20 \mathrm{mg} \text {, } \\
\text { but not cetirizine } 10 \mathrm{mg} \text {, reached } \\
\text { maximum response in a statistically } \\
\text { significant shorter time than placebo }\end{array}$ \\
\hline $\begin{array}{l}\text { Horak } \\
\text { et } \mathrm{al}^{20}\end{array}$ & $\begin{array}{l}\text { Asymptomatic patients }(\mathrm{n}=75) \text {. } \\
\text { Double-blind cross-over, allergen- } \\
\text { induced symptoms in the Vienna } \\
\text { Challenge, single dose, bilastine } 20 \mathrm{mg} \text {, } \\
\text { cetirizine } 10 \mathrm{mg} \text {, fexofenadine } 120 \mathrm{mg}\end{array}$ & $\begin{array}{l}\text { Reflective NSS in patients challenged } \\
\text { with allergen for } 6 \text { hours }\end{array}$ & $\begin{array}{l}\text { Bilastine and cetirizine had a rapid } \\
\text { onset of action, within I hour, } \\
\text { duration of action greater than } \\
26 \text { hours. Fexofenadine was less } \\
\text { effective on day two }\end{array}$ \\
\hline
\end{tabular}

Abbreviations: AUC-TSS, the area under curve of total symptom scores; NNSS, nonnasal symptom scores; NSD, no significant differences; NSS, nasal symptom scores; T2OSS, total 2-ocular symptom scores; T4NSS, reflective and instantaneous total 4-nasal symptom scores; T6SS, total 6-symptom scores.

15 minutes. Four of these symptoms (rhinorrhea, nasal congestion, sneezing, and nasal itching) were considered to be the principal study variables. The treatments studied were $20 \mathrm{mg}$ of bilastine, $10 \mathrm{mg}$ of cetirizine, $120 \mathrm{mg}$ of fexofenadine, or a placebo, administered 2 hours after the first provocation. In this study, onset of action was observed at around 1 hour for bilastine and cetirizine, with duration of action of at least 26 hours. The duration of action of fexofenadine was considered shorter, given the fact that it was less effective on the second day of the study. ${ }^{20} \mathrm{~A}$ similar study compared the effect of 20 and $50 \mathrm{mg}$ of bilastine to $10 \mathrm{mg}$ of cetirizine with respect to the inhibition of cutaneous wheal and flare following a skin prick test at different times in relation to the drug administration. The response was similar for $20 \mathrm{mg}$ of bilastine and $10 \mathrm{mg}$ of cetirizine at the different measurement points, with the exception of the analysis obtained 1.5 hours following administration, which indicated that bilastine had a faster onset of action. The administration of $50 \mathrm{mg}$ of bilastine prolonged the duration of the antihistaminic effect. ${ }^{21}$ In a study on healthy volunteers, the results observed showed the existence of a certain dose dependency in regards to the inhibition of wheals following subcutaneously administered histamine. $^{3}$

\section{Clinical studies}

\section{Allergic rhinoconjunctivitis (seasonal and perennial)}

H1 antihistamines are first line drugs for the treatment of allergic rhinoconjunctivitis. Allergic rhinitis is one of the most common chronic diseases in the world, with an estimated prevalence of $10 \%-25 \% .{ }^{22}$ The most frequent 
symptoms of allergic rhinitis are nasal itching, sneezing fits, rhinorrhea, and nasal obstruction. ${ }^{23}$ Patients with allergic rhinitis show a reduced quality of $\operatorname{life}^{24}$ due to the inherent symptoms of rhinitis and the physiopathology, which can result in sleep disorders. ${ }^{25}$

The nasal response to allergen stimulation provokes all the symptoms characteristic of allergic rhinitis. This response comprises two phases: the immediate response is observed 20 minutes after contact with the allergen and can continue for up to hours afterwards. This is primarily the result of mast cell degranulation. This phase is characterized by itching, sneezing, and rhinorrhea. Mast cells release chemotactic substances and cytokines that are able to attract other cells to the inflammatory focus, including eosinophils. This gives rise to the late phase of the allergic response (48 hours later), which comprises the cellular response. The principal response in this phase is nasal obstruction. ${ }^{26}$

Histamine is one of the substances released by the mast cells and basophils. This amine is released in a few seconds in E immunoglobulin (IgE) mediated hypersensitivity reactions. A minute after the nasal allergic stimulation, the histamine released reaches its maximum concentration. Ten minutes after this peak, there is an abrupt drop in concentration. ${ }^{27}$ Histamine induces increased chemotaxis of eosinophils, increased cytokine (IL-1 $\beta$, IL-6, IL-4, and IL-5) release, increased vascular cell adhesion molecule (VCAM)-1 expression and activation of nuclear factor (NF)- $\kappa \beta$. Histamine is responsible for the characteristic symptomatology of allergic rhinitis, including nasal obstruction.

$\mathrm{H} 1$ antihistamines can act through different routes of action; they counteract the effects of histamine on the $\mathrm{H} 1$ receptors and they are also able to inhibit the release from mast cells and basophils, which contribute to the late phase of the allergic response. ${ }^{28}$ Bilastine is a highly selective antihistamine, with moderate to high $\mathrm{H} 1$ receptor affinity. Furthermore, in vitro studies have shown anti-inflammatory activity by inhibiting the release of histamine, IL-4, and tumor necrosis factor (TNF)- $\alpha$, and also by inducing the release of different stimulants. ${ }^{5}$

The efficacy of bilastine in allergic rhinoconjunctivitis has been confirmed in several studies comparing it to either a placebo or to other antihistamines.

Bachert et al conducted a multicenter study to assess clinical efficacy through the rating of nasal and nonnasal symptoms at the start and after 14 days of treatment, and the safety of $20 \mathrm{mg}$ of bilastine compared to $5 \mathrm{mg}$ of desloratadine and placebo in patients with seasonal allergic rhinitis $(n=721)$. A significant decrease was observed in the nasal and nonnasal symptoms of patients treated with both drugs in relation to the placebo. Along these same lines, a reduction in the patient-rated discomfort score and an improvement in the investigator's overall clinical impression were observed. However, no differences were found between bilastine and desloratadine. ${ }^{29}$

A further study compared the administration of $20 \mathrm{mg}$ of bilastine to $10 \mathrm{mg}$ of cetirizine or placebo in patients with seasonal rhinitis, finding statistically significant differences in the improvement of the nasal symptoms in the group administered with bilastine ( $-43.8 \%$ after 7 days and $-48.5 \%$ after 14 days) and cetirizine ( $-40.2 \%$ after 7 days, and $-50.6 \%$ after 14 days $)$ in relation to the placebo group $(P<0.001)$, yet without any differences between treatment groups. ${ }^{30}$

Daily treatment with $2 \mathrm{mg}$ of bilastine was effective for the treatment of perennial allergic rhinitis, a disease which affects a high percentage of the population $(10 \%-15 \%)$. An assessment was made of the nasal symptoms (rhinorrhea, sneezing, congestion, itching) and eye symptoms (redness, tears) compared to the placebo; the results showed bilastine and cetirizine were similar in Europe and superior in Argentina, achieving an approximate 34\% reduction in nasal symptoms after 28 days of treatment. ${ }^{31}$

Bartra et al reviewed clinical trials conducted with bilastine in order to assess its effect on eye symptoms of allergic rhinoconjunctivitis (itching, redness, and tearing). The clinical test results showed bilastine to be as effective as the comparator drugs for controlling the eye symptoms in seasonal allergic rhinitis. ${ }^{32}$

Likewise, an evaluation of the effects of bilastine on nasal obstruction in allergic rhinitis was performed. The efficacy of $20 \mathrm{mg}$ of bilastine for controlling this symptom was tested and was determined to be along the same lines as that observed with active comparators (desloratadine $5 \mathrm{mg}$ and cetirizine $10 \mathrm{mg}$ ). ${ }^{23}$

The quality of life variable was also recently analyzed separately, given the fact that it has been studied as a secondary objective in three clinical studies on allergic rhinitis, by means of the Rhinoconjunctivitis Quality of Life Questionnaire (RQLQ) questionnaire on a total number of 2335 patients and in chronic urticaria through the Dermatology Life Quality Index (DLQI) questionnaire on a total of 525 patients, compared to levocetirizine and placebo. ${ }^{33}$ The results are parallel to the efficacy results observed in the clinical trials.

\section{Chronic urticaria}

Chronic urticaria significantly affects patients' quality of life. It is characterized by the appearance of pruritic 
erythematous papules. The papules have a duration of less than 24 hours in which they may appear daily or more than once a week for 6 weeks. In $50 \%$ of cases, this is associated with the appearance of angioedema. ${ }^{34}$

The clinical guidelines for the treatment of chronic urticaria suggest increasing the normal dosage of the antihistamine by up to 4-fold, if the normal therapeutic dosing is not effective. ${ }^{35}$ However, in the literature, there are no randomized, double blind trials that study whether there is any difference in efficacy between the therapeutic doses and higher doses for controlling chronic urticaria. In this respect, preliminary data with bilastine are available, such as the data obtained in a phase I double blind single dose clinical trial with four crossover periods on 21 volunteers administered with either placebo, $10 \mathrm{mg}$ of cetirizine, or $2.5,5,10$, or $50 \mathrm{mg}$ of bilastine. An evaluation of the relationship between the dose of bilastine and the inhibition of the cutaneous response to histamine (measured by wheal and flare) was made. All bilastine doses inhibited the histamine-induced wheal between 1.5 and 12 hours and the flare between 4 and 24 hours following administration, showing a response that is similar or better than cetirizine. No clear dose dependent effect was observed, although it was seen that the 20 and $50 \mathrm{mg}$ dose levels had a longer lasting effect. ${ }^{13}$

Audicana et al conducted a phase II study on 222 patients with chronic urticaria. The effect of bilastine $(10,20$, and $30 \mathrm{mg}$ ) was evaluated against a placebo in the control group for the appearance of papules and itching. Statistically significant differences were observed in the three treatment groups administered bilastine compared to the placebo group, although no dose dependent effect was observed, as reported by Ferrer et al. ${ }^{36}$

Bilastine was also assessed in a double blind controlled clinical trial with placebo and levocetirizine both administered for 28 days. A compound variable was evaluated by calculating the data for itching, number of wheals, and the maximum size of the wheals, based on patients' diaries. The symptoms were reduced from the second day of treatment with $20 \mathrm{mg}$ of bilastine, which was also the case for levocetirizine, showing better results than placebo. ${ }^{37}$

\section{Tolerance and safety}

In the various studies conducted during the preclinical development of bilastine, no significant toxicity was demonstrated. The acute toxicity of bilastine was investigated through the oral and intravenous administration in mice and rats. Following the oral administration of 5000 and $2000 \mathrm{mg} / \mathrm{kg}$ in mice and rats respectively, no mortality was observed in either of the two species. However, following intravenous administration, the lethal dose for $50 \%$ of the animals was $33 \mathrm{mg} / \mathrm{kg}$ for mice and $45-75 \mathrm{mg} / \mathrm{kg}$ for rats. ${ }^{38}$

In chronic toxicity studies of bilastine administered both orally and intravenously, no signs of toxicity were observed in any organ. ${ }^{38}$ No effects on fertility, either on embryo-fetal toxicity or on teratogenicity, were observed in the studies conducted on mice and rabbits. ${ }^{39}$

When studies were conducted on humans during the assessment of the efficacy of bilastine in the treatment of chronic urticaria and allergic rhinitis, tolerability was studied in relation to a placebo and other antihistamines (levocetirizine, desloratadine, and cetirizine), and most of the data correspond to the therapeutic dose of $10 \mathrm{mg}$ a day; Table 3 shows results of these clinical trials. Specific studies were also conducted to evaluate the incidence of problems commonly associated with the use of antihistamines, such as drowsiness and heart rate changes.

In general, bilastine was well tolerated and the majority of the adverse events described were either mild or moderate. The incidence of drug related adverse effects was 15\%-30\%, similar to observed with the placebo. There were no serious drug related adverse effects in any of the clinical trials. No significant changes were detected in vital signs (heart rate or blood pressure), in the electrocardiogram (ECG) parameters or in laboratory values (hematology and liver and kidney function). ${ }^{29,30,37}$

The adverse events most commonly described by patients treated with bilastine and to some extent related to the drug, are: headache, drowsiness, dizziness, and fatigue..$^{29,30,37,40}$ In a study in which the treatment was administered for 1-year, the most commonly described adverse effects were headache $(9.6 \%)$ followed by nasopharyngitis $(2.5 \%)$, while other less common bilastine related adverse effects included some changes in the ECG trace, which were not consistent over time. ${ }^{31}$

No differences were observed in the tolerance of bilastine compared to cetirizine and desloratadine..$^{29,37}$ One study described a statistically significant minor incidence in the appearance of drowsiness, (bilastine and cetirizine, $1.8 \%$ versus $7.5 \%$ ) and fatigue, (bilastine and cetirizine, $0.4 \%$ versus $4.8 \%$ ) with $20 \mathrm{mg}$ a day of bilastine compared to cetirizine at normal dose levels. ${ }^{30}$

Some second generation antihistamines have been associated with adverse cardiac effects, such as the prolongation of the QT interval and the development of torsades de pointes. These effects have been attributed to the direct blocking of the potassium channels. For this reason, and following the guidelines of International Conference on Harmonisation (ICH) E14, a study was conducted to evaluate the effect of 
Table 3 Bilastine tolerability determined during clinical investigation

\begin{tabular}{|c|c|c|c|c|}
\hline Author & $\begin{array}{l}\text { Type of patients, number, } \\
\text { and length of treatment }\end{array}$ & Bilastine tolerability & $\begin{array}{l}\text { Active comparator } \\
\text { tolerability }\end{array}$ & Placebo tolerability \\
\hline \multirow[t]{4}{*}{ Bachert et al ${ }^{29}$} & Seasonal allergic rhinitis $(n=72 \mathrm{I})$ & $21 \%$ & $20 \%$ & $19 \%$ \\
\hline & 14 days; bilastine $20 \mathrm{mg}$ & Headache $12 \%$ & Headache II.2\% & Headache $10.2 \%$ \\
\hline & desloratadine $5 \mathrm{mg}$, and placebo & Somnolence $3.9 \%$ & Somnolence $3.7 \%$ & Somnolence $2.4 \%$ \\
\hline & & Fatigue $2.6 \%$ & Fatigue $1.2 \%$ & Fatigue $2.4 \%$ \\
\hline \multirow[t]{5}{*}{ Kuna et $\mathrm{al}^{30}$} & Seasonal allergic rhinitis $(n=68 \mathrm{I})$ & $14.5 \%$ & $24.6 \%$ & $19.5 \%$ \\
\hline & I4 days; bilastine 20 mg, & Headache $10.6 \%$ & Headache $8.3 \%$ & Headache $13.7 \%$ \\
\hline & cetirizine $10 \mathrm{mg}$, and placebo & Somnolence I.8\% & Somnolence $7.5 \%$ & Somnolence $2.2 \%$ \\
\hline & & Fatigue $0.4 \%$ & Fatigue $4.8 \%$ & Fatigue $3.1 \%$ \\
\hline & & Dyspnea $0.9 \%$ & Dyspnea $2.2 \%$ & Dyspnea $0.9 \%$ \\
\hline \multirow[t]{4}{*}{ Zuberbier et $\mathrm{al}^{37}$} & Chronic idiopathic urticarial & $30.1 \%$ & $26.7 \%$ & $22.8 \%$ \\
\hline & $(\mathrm{n}=525) ; 28$ days; bilastine $20 \mathrm{mg}$ & Headache $12.1 \%$ & Headache $12.1 \%$ & Headache $9.2 \%$ \\
\hline & levocetirizine $5 \mathrm{mg}$, and placebo & Somnolence $5.8 \%$ & Somnolence $6.7 \%$ & Somnolence $3.3 \%$ \\
\hline & & Fatigue $2.9 \%$ & - & Fatigue $2.7 \%$ \\
\hline \multirow[t]{3}{*}{ Sastre et $\mathrm{a}^{31}$} & Perennial allergic rhinitis $(n=650)$; & $23.4 \%$ & $19.8 \%$ & $27.9 \%$ \\
\hline & 4 weeks; bilastine $20 \mathrm{mg}$, & Headache $10.7 \%$ & Headache $5.1 \%$ & Headache $13.7 \%$ \\
\hline & cetirizine $10 \mathrm{mg}$, and placebo & Somnolence $13.7 \%$ & Somnolence $6.9 \%$ & Somnolence $3.2 \%$ \\
\hline \multirow[t]{5}{*}{ Sastre et $\mathrm{al}^{31}$} & Perennial allergic rhinitis $(n=5 \mid 3)$; & $31 \%$ & - & - \\
\hline & I-year, bilastine 20 mg & Headache $9.6 \%$ & & \\
\hline & & Somnolence $1.4 \%$ & & \\
\hline & & Nasopharyngitis $2.5 \%$ & & \\
\hline & & QT wave prolongation I.8\% & & \\
\hline
\end{tabular}

the $20 \mathrm{mg}$ therapeutic dose and that of a supratherapeutic dose of $100 \mathrm{mg}$ on the QTc interval. This was a multidose randomized double blind crossover study with placebo and with $400 \mathrm{mg}$ moxifloxacin, the latter an active comparator responsible for changes of this type. A fifth arm was included in which a $20 \mathrm{mg}$ dose of bilastine in combination with the administration of $400 \mathrm{mg}$ of ketoconazole. No effects with either $20 \mathrm{mg}$ or $100 \mathrm{mg}$ of bilastine were observed on the electrocardiogram trace, the QTc duration, or on the T wave morphology. The increase in the value of the ATc interval of 5 milliseconds or less confirms this lack of influence. No significant effects on the QTc interval were observed with any of the doses evaluated. The changes reported in the combination of bilastine with ketoconazole were related to the antifungal drug, given the fact that the plasma concentrations of bilastine in this coadministration were less than those observed with the supratherapeutic dose of $100 \mathrm{mg} .{ }^{41,42}$ These results are consistent with other investigations on bilastine and in clinical trials with patients in which no changes in the electrocardiogram or cardiac related adverse effects were observed.

The evaluation of neurological tolerance was conducted with specific studies to evaluate the appearance of drowsiness/sedation and the effect on attention when driving a vehicle following bilastine treatment. The sedating effect of first generation antihistamines is widely known, which in some cases has led these drugs to be used as sleeping pills. ${ }^{43}$ This effect is related to the affinity for the
P glycoprotein, which is responsible for the efflux of drugs and other substances from the central nervous system, and to drug lipophilicity; the greater the affinity and the lower the lipophilicity, the lower the blood-brain barrier crossing.

In a repeat dose crossover trial with healthy volunteers, three doses of bilastine (20,40, and $80 \mathrm{mg}$ ) were compared to $25 \mathrm{mg}$ of hydroxyzine and placebo following 7 days of treatment and with a washout period of 15 days between each scheduled administration. An evaluation was made of the effects on psychomotor function (motor activity, perception, attention, associative integration) and state of mind. Hydroxyzine caused an increase in the time to react, a decrease in the blinking rate, and a worsening of attention or motor activity. With the 20 and $40 \mathrm{mg}$ doses of bilastine, no changes were observed in the parameters evaluated, although changes were observed with the highest dose $(80 \mathrm{mg})$ when evaluating objective parameters. Subjectively, only the $20 \mathrm{mg}$ dose was distinguishable from the placebo. ${ }^{3}$

A clinical trial was conducted with 22 healthy volunteers, who were administered daily doses of bilastine $(20 \mathrm{mg}$ and $40 \mathrm{mg}$ ) for an 8-day period, and compared to a placebo and $50 \mathrm{mg}$ a day of hydroxyzine (positive control) to evaluate the effect of the drug on driving. This was a crossover study with a 7-day interval between treatment periods. The position of the car was evaluated at a constant speed, recording the deviation of the car in relation to the standard deviation of lateral position. No changes were observed with the 20 and 
$40 \mathrm{mg}$ doses of bilastine, providing results similar to the placebo, with evaluations made on the first and eighth day of treatment. With hydroxyzine, a significant increase was observed in the deviations for all measurements, although it was reduced in relation to the first administration, in a situation of pharmacokinetic balance, following the final dose. $^{44}$

In the overall analysis of the data on the development of sleepiness observed in the different studies conducted with bilastine, it was concluded that its appearance is similar to that observed with a placebo, and significantly less than that observed with cetirizine. ${ }^{45}$

Further studies have been conducted to evaluate the effects of bilastine on the central nervous system in combination with other drugs such as lorazepam or substances such as alcohol, whose sedative effect is well known. None of these studies with $20 \mathrm{mg}$ of bilastine produced such an effect, neither did they increase the effect produced by these known central nervous system depressants. ${ }^{18,19}$

\section{Conclusion}

Bilastine is a second generation antihistamine developed for the treatment of allergic rhinoconjunctivitis and chronic urticaria. It is a product that does not undergo hepatic metabolism nor does it modify the activity of the cytochrome P450 isoenzymes. It should not be administered at meal times, which may increase its bioavailability. Treatment with $20 \mathrm{mg}$, administered orally, is effective in controlling the symptoms and improving the quality of life of these patients. The studies conducted to date indicate that bilastine has an acceptable tolerability profile, given the fact that no cardiotoxic effects have been observed, and the therapeutic dose does not change a patient's state of alertness.

\section{Disclosure}

The authors report no conflicts of interest in this work.

\section{References}

1. Brozek JL, Bousquet J, Baena-Cagnani CE, et al; Global Allergy and Asthma European Network; Grading of Recommendations Assessment, Development and Evaluation Working Group. Allergic rhinitis and its impact on asthma (ARIA) guidelines: 2010 revision. J Allergy Clin Immunol. 2010;126(3):466-476.

2. Corcóstegui R, Labeaga L, Innerárity A, Berisa A, Orjales A. Preclinical pharmacology of bilastine, a new selective histamine $\mathrm{H} 1$ receptor antagonist: receptor selectivity and in vitro antihistaminic activity. Drugs R D. 2005;6(6):371-384.

3. García-Gea C, Martínez-Colomer J, Antonijoan RM, Valiente R, Barbanoj MJ. Comparison of peripheral and central effects of single and repeated oral dose administrations of bilastine, a new $\mathrm{H} 1$ antihistamine: a dose-range study in healthy volunteers with hydroxyzine and placebo as control treatments. J Clin Psychopharmacol. 2008;28(6):675-685.
4. Corcóstegui R, Labeaga L, Innerárity A, Berisa A, Orjales A. In vivo pharmacological characterisation of bilastine, a potent and selective histamine H1 receptor antagonist. Drugs $R$ D. 2006;7(4): 219-231.

5. Alvarez-Mon M, San Antonio E, Lucero M, Sanz E, Ledo F, De la Hera A. Bilastine, a novel antihistamine that preferentially inhibits histamine and interleukin-4 release from human mast cells and granulocytes. Allergy. 2009;64(Suppl 90):555.

6. Sologuren A, Valiente R, Crean C, McLaverty D. Relationship of dose to inhibition of wheal and flare for 5 doses of bilastine and $10 \mathrm{mg}$ cetirizine. 36th Annual Meeting of the American College of Clinical Pharmacology; September 9-11, 2007; San Francisco, USA. J Clin Pharmacol. 2007;47(9):1198. Abstract 69.

7. Jauregizar N, de la Fuente L, Lucero ML, Sologuren A, Leal N, Rodríguez M. Pharmacokinetic-pharmacodynamic modelling of the antihistaminic (H1) effect of bilastine. Clin Pharmacokinet. 2009; 48(8):543-554.

8. Crean C, Roupe K, Sologuren A, Valiente R. The pharmacokinetics of bilastine after single and 14 days once daily administration. 8th Congress of the European Association of Clinical Pharmacology and Therapeutics; August 29-September 1, 2007; Amsterdam, The Netherlands. Basic Clin Pharmacol Toxicol. 2007;101(Suppl 1):148. Abstract P252.

9. Bailey DG. Fruit juice inhibition of uptake transport: a new type of food-drug interaction. Br J Clin Pharmacol. 2010;70:645-655.

10. Bilastine SPC. Texto propuesto para la ficha técnica Bilastina $20 \mathrm{mg}$ [Summary of Product Characteristics for Bilastine $20 \mathrm{mg}$.] Available from: http://www.aemps.gob.es/cima/especialidad.do?metodo=verFi chaWordPdf $\&$ codigo $=73027 \&$ formato $=$ pdf $\&$ formulario $=$ FICHAS $\&$ file=ficha.pdf. Accessed February 20, 2013. Spanish.

11. Crean C, Valiente R, Sologuren A, McLaverty D. Effect of grapefruit juice on the pharmacokinetics of bilastine. 36th Annual Meeting of the American College of Clinical Pharmacology; September 9-11, 2007; San Francisco, USA. J Clin Pharmacol. 2007;47(9):1198. Abstract 71.

12. Mumford R, Allan L, Hoey R, et al. The disposition, metabolism and elimination in rats of bilastine, a potent, selective $\mathrm{H} 1$ receptor antagonist. 8th International ISSX Meeting; October 9-12, 2007; Sendai, Japan. Drug Metab Rev. 2007;39(Suppl I):200-201. Abstract 282.

13. Sologuren A, Lucero ML, Valiente R, Valiente R, Charles H, Mair SJ. Human mass balance with [14C]-bilastine following oral administration to healthy volunteers. 9th Congress of the European Association for Clinical Pharmacology and Therapeutics; July 12-15, 2009; Edinburgh, UK. Basic Clin Pharmacol Toxicol. 2009;105(Suppl 1):106-107. Abstract TP85.

14. Crean C, Sologuren A, Valiente R, McLaverty D. The drug-drug interaction of ketoconazole on bilastine pharmacokinetics. 8th Congress of the European Association of Clinical Pharmacology and Therapeutics; August 29-September 1, 2007; Amsterdam, The Netherlands. Basic Clin Pharmacol Toxicol. 2007;101(Suppl 1): 148-149. Abstract P253.

15. Rodríguez M, Lucero ML, Orjales A, Gonzalo A, Leal N, Calvo R. Estimation of bilastine dose in paediatrics. IX World Conference on Clinical Pharmacology Therapeutics; July 27-August 1, 2008; Quebec City, Canada. Can J Clin Pharmacol. 2008;15(3):e680. Abstract 554.

16. Bousquet J, Ansótegui I, Canonica GW, et al. Establishing the place in therapy of bilastine in the treatment of allergic rhinitis according to ARIA: evidence review. Curr Med Res Opin. 2012;28(1): 131-139.

17. Takano M, Hasegawa R, Fukuda T, Yumoto R, Nagai J, Murakami T. Interaction with P-glycoprotein and transport of erythromycin, midazolam and ketoconazole in Caco-2 cells. Eur $J$ Pharmacol. 1998;358(3):289-294.

18. Bachert C, Kuna P, Zuberbier T. Bilastine in allergic rhinoconjunctivitis and urticaria. Allergy. 2010;65(Suppl 93):S1-S13. 
19. García-Gea C, Clos S, Antonijoan RM, Gich I, Valiente R, Barbanoj MJ Crossover, randomised, double-blind, double-dummy, placebo and positive standard-controlled, unicenter clinical trial to assess the possible interaction on CNS effects between bilastine $(20 \mathrm{mg}$ and $80 \mathrm{mg}$ ) and alcohol $(0.8 \mathrm{~g} / \mathrm{kg})$ after single simultaneous administration in healthy subjects. 20th Congress of the Spanish Clinical Pharmacology Society; October 29-November 2, 2006; Tenerife, Spain. Basic Clin Pharmacol Toxicol. 2006;99(Suppl I):30. Abstract EC13.

20. Horak F, Zieglmayer P, Zieglmayer R, Lemell P. The effects of bilastine compared with cetirizine, fexofenadine, and placebo on allergen-induced nasal and ocular symptoms in patients exposed to aeroallergen in the Vienna Challenge Chamber. Inflamm Res. 2010;59(5):391-398.

21. Cruch MK. Comparative inhibition by bilastine and cetirizine of histamine-induced wheal and flare response in humans. Inflamm Res. 2011;60(12):1107-1112.

22. Bousquet J, Khaltaev N, CruzAA, et al. Allergic Rhinitis and its Impact on Asthma (ARIA) 2008 update. Allergy. 2008;63(86):8-160.

23. Dávila I, Sastre J, Mullol J, et al. Effect of bilastine upon nasal obstruction. J Investig Allergol Clin Immunol. 2011;21(Suppl 3):2-8.

24. Juniper EF, Rohrbaugh T, Meltzer EO. A questionnaire to measure quality of life in adults with nocturnal allergic rhinoconjunctivitis. J Allergy Clin Immunol. 2003;111(3):484-490.

25. Woods L, Craig TJ. The importance of rhinitis on sleep, daytime somnolence, productivity and fatigue. Curr Opin Pulm Med. 2006 12(6):390-396.

26. Gelfand EW. Inflammatory mediators in allergic rhinitis. J Allergy Clin Immunol. 2004;114(Suppl 5):S135-S138.

27. Wang D, Smitz J, Waterschoot S, Clement P. An approach to the understanding of the nasal early-phase reaction induced by nasal allergen challenge. Allergy. 1997;52(2):162-167.

28. Schroeder JT, Schleimer RP, Lichtenstein LM, Kreutner W. Inhibition of cytokine generation and mediator release by human basophils treated with desloratadine. Clin Exp Allergy. 2001;31(9):1369-1377.

29. Bachert C, Kuna P, Sanquer F; Bilastine International Workin Group. Comparison of the efficacy and safety of bilastine $20 \mathrm{mg}$ vs desloratadine $5 \mathrm{mg}$ in seasonal allergic rhinitis patients. Allergy. 2009; 64(1):158-165.

30. Kuna P, Bachert C, Nowacki Z, et al; Bilastine International Working Group. Efficacy and safety of bilastine $20 \mathrm{mg}$ compared with cetirizine $10 \mathrm{mg}$ and placebo for the symptomatic treatment of seasonal allergic rhinitis: a randomized, double-blind, parallel-group study. Clin Exp Allergy. 2009;39(9):1338-1347.

31. Sastre J, Mullol J, Valero A, Valiente R; Bilastine Study Group. Efficacy and safety of bilastine $20 \mathrm{mg}$ compared with cetirizine $10 \mathrm{mg}$ and placebo in the treatment of perennial allergic rhinitis. Curr Med Res Opin. 2012;28(1):121-130.

32. Bartra J, Mullol J, Montoro J, et al. Effect of bilastine upon the ocular symptoms of allergic rhinoconjunctivitis. J Investig Allergol Clin Immunol. 2011;21(Suppl 3):24-33.
33. Jáuregui I, Bartra J, del Cuvillo A, et al. Bilastine and quality of life. J Investig Allergol Clin Immunol. 2011;21(Suppl 3):16-23.

34. Kaplan AP. Chronic urticaria: pathogenesis and treatment. J Allergy Clin Immunol. 2004;114(3):465-474.

35. Zuberbier T, Asero R, Bindslev-Jensen C, et al; Dermatology Section of the European Academy of Allergology and Clinical Immunology; Global Allergy and Asthma European Network; European Dermatology Forum; World Allergy Organization. EAACI/GA(2)LEN/EDF/WAO guideline: management of urticaria. Allergy. 2009;64(10):1427-1443.

36. Ferrer M, Sastre J, Jáuregui I, et al. Effect of antihistamine up-dosing in chronic urticaria. J Investig Allergol Clin Immunol. 2011;21(Suppl 3): 34-39.

37. Zuberbier T, Oanta A, Bogacka E, et al; Bilastine International Working Group. Comparison of the efficacy and safety of bilastine $20 \mathrm{mg}$ vs levocetirizine $5 \mathrm{mg}$ for the treatment of chronic idiopathic urticaria: a multi-centre, double-blind, randomized, placebo-controlled study. Allergy. 2010;65(4):516-528.

38. Arteche JK, Ledo F, Casadesus A, et al. Bilastine. Preclinical toxicology review. XII International Congress of Toxicology; July 19-23, 2010; Barcelona, Spain. Toxicol Lett. 2010;196(Suppl):S256. Abstract P302-026.

39. Sommer E, Weber K, Lucero ML, Arteche JK, Orjales A. Oncogenicity risk assessment of bilastine, a novel antihistamine compound. 45 th Congress of the European Societies of Toxicology (Eurotox); October 5-8, 2008; Rothes, Greece. Toxicol Lett. 2008;180(Suppl):S156. Abstract P20.

40. Carter NJ. Bilastine: in allergic rhinitis and urticaria. Drugs. 2012; 72(9):1257-1269.

41. Graff C, Struijk JJ, Kanters JK, Andersen MP, Toft E, Tyl B. Effects of bilastine on T-wave morphology and the QTc interval. A randomized, double-blind, placebo-controlled, thorough QTc study. Clin Drug Investig. 2012;32(5):339-351.

42. Tyl B, Kabbaj M, Azzam S, et al. Lack of significant effect of bilastine administered at therapeutic and supratherapeutic doses and concomitantly with ketoconazole on ventricular repolarization: results of a thorough QT study (TQTS) with QT-concentration analysis. J Clin Pharmacol. 2012;52(6):893-903.

43. Richardson GS, Roehrs TA, Rosenthal L, Koshorek G, Roth T. Tolerance to daytime sedative effects of $\mathrm{H} 1$ antihistamines. J Clin Psychopharmacol. 2002;22(5):511-515.

44. Conen S, Theunissen EL, Van Oers AC, Valiente R, Ramaekers JG. Acute and subchronic effects of bilastine (20 and $40 \mathrm{mg}$ ) and hydroxyzine (50 $\mathrm{mg}$ ) on actual driving performance in healthy volunteers. J Psychopharmacol. 2011;25(11):1517-1533

45. Montoro J, Mullol J, Daáila I, et al. Bilastine and the central nervous system. J Investig Allergol Clin Immunol. 2011;21(Suppl 3):9-15.
Therapeutics and Clinical Risk Management

\section{Publish your work in this journal}

Therapeutics and Clinical Risk Management is an international, peerreviewed journal of clinical therapeutics and risk management, focusing on concise rapid reporting of clinical studies in all therapeutic areas, outcomes, safety, and programs for the effective, safe, and sustained use of medicines. This journal is indexed on PubMed Central, CAS,

\section{Dovepress}

EMBase, Scopus and the Elsevier Bibliographic databases. The manuscript management system is completely online and includes a very quick and fair peer-review system, which is all easy to use. Visit http://www.dovepress.com/testimonials.php to read real quotes from published authors. 